Original article

\title{
İlkokul 3. ve 4. Sınıf Öğrencilerinin Covid-19 Kavramına İlişkin Bilişsel Yapılarının İncelenmesi
}

\section{Cognitive Structures of Primary School, $3^{\text {rd }}$ and $4^{\text {th }}$ Grade Students Related to Covid-19 Concept}

\author{
Berk Keleş (1) a, * \& Pınar Ural Keleş (i) a \\ a Graduate Student, ÇOMÜ Graduate Education Institute, Çanakkale Onsekiz Mart University, Çanakkale, Turkey

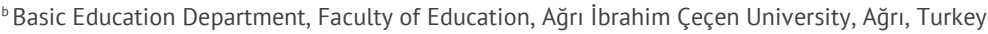

\begin{abstract}
Özet
Bu çalışmanın amacı; ilkokul 3. ve 4. sınıf öğrencilerinin Covid-19 kavramına ilişkin bilişsel yapılarının incelenmesidir. Tarama modeli kullanılarak yapılan çalışmada veriler; öğrencilerin Covid 19 kavramına ilişkin çizimlerinden ve açıklamalarından elde edilmiştir. Çalışmanın örneklemini 3. sınıf düzeyinden 86 ve 4. sınıf düzeyinden 77 öğrenci olmak üzere toplam 163 öğrenci oluşmaktadır. Elde edilen veriler içerik analizi kullanılarak analiz edilmiştir. Çalışmada 3. ve 4. sınıf öğrencilerinin Covid 19 kavramına ilişkin çizimlerinden 10, açıklamalarından 10 bilişsel yapı elde edilmiştir. Elde edilen bu bilişsel yapıların çoğunun öğrencilerin çizim ve açıklamalarında ortak olduğu belirlenmiştir. Çalışma sonucunda ilkokul 3. ve 4. sınıf öğrencilerinin Covid 19 kavramına ilişkin geliştirdikleri bilişsel yapıların geniş bir perspektifte dağılım gösterdiği tespit edilmiştir. Çalışmada ayrıca kavramla ilgili öğrencilerin geliştirdikleri en kuvvetli bilişsel yapıların “Covid-19'dan Korunma” ve “Covid-19'un Sebebi” olduğu belirlenirken pandemi sürecinin öğrencilerin psikolojileri üzerine olumsuz etkiler yaptığına ilişkin bulgulara rastlanmıştır. Katılımcıların niceliksel ve niteliksel özellikleri genişletilerek ve farklı ölçme araçları kullanılarak benzer yönde araştırmalar yapılması çalışmanın önerileri arasındadır.
\end{abstract}

Anahtar Kelimeler: Covid 19 kavramı, bilişsel yapılar, çizme yazma tekniği, üçüncü ve dördüncü sınıf öğrencileri.

\begin{abstract}
The aim of this study is to examine the cognitive structures of primary school, 3rd and 4th grade students regarding the Covid-19 concept. The data in the study were gathered by using the scanning model; they have been obtained from students' drawings and explanations related the Covid 19 concept. The sample of the study consists of total 163 students, 86 of participants are third year students and 77 are fourth year students. Content analysis method was used to analyze obtained data. In the study, 10 cognitive structures were obtained from the drawings of 3rd and 4th grade students regarding the Covid 19 concept and 10 cognitive structures from their explanations. It was determined that most of these cognitive structures were common in students' drawings and explanations. As a result of the study, it was determined that the cognitive structures developed by primary school $3 \mathrm{rd}$ and 4th grade students regarding the concept of Covid 19 were distributed in a wide perspective. In the study, it was also determined that the most powerful cognitive structures developed by the students regarding the concept were "Protection from Covid-19" and "The Cause of Covid-19". Data indicating pandemic process had negative effects on students' psychology were obtained. It is among
\end{abstract}

\footnotetext{
" Corresponding author:

Keleş, M. Berk. He is a pre-school education graduate student at Çanakkale 18 Mart University. His research interests include preschool science education and entrepreneurship. He lives in Ağrı.

Email: berk_keles_61@yahoo.com
} 


\section{GíRiş}

Günümüz dünyasında virüslerin pozitif ve negatif olarak barındırdıkları potansiyeller oldukça fazla dikkat çekmekte bu canlıların farklı canlıları enfekte etme, hastalık durumu yaratma, tedavi sürecinde aşı olarak kullanılmalarının yanı sıra biyolojik silah veya genetik mühendisliğindeki kullanım alanları onları insanoğlu için daha önemli hale getirmektedir (Takmaz ve Yılmaz, 2020; Topal, 2006). Virüsler içinde yer alan koronavirüsler ise insan veya hayvanlarda hastalığa neden olabilecek büyük bir virüs ailesidir. Koronavirüslerin insanlarda Orta Doğu Solunum Sendromu (MERS) ve Şiddetli Akut Solunum Sendromu (SARS) gibi şiddetli solunum yolu enfeksiyonlarına neden olduğu bilinmektedir (WHO, 2020). İlk kez Çin'in Wuhan kentinde tanımlanan ve "COVID-19" adı verilen solumum yolu rahatsızlı̆̆ından da koronavirüsler sorumludur (UNICEF, 2020). Hızlı bir şekilde tüm dünyayı tehdit eden hastalık 11 Mart'ta Dünya Sağlık Örgütü (WHO) tarafından "pandemi” olarak adlandırılmaya başlanmıştır (WHO, 2020). Dünya sağl1k örgütü 15 Aralık 2020 tarihi itibariyle dünya genelinde 1.618.374 ölüm dâhil olmak üzere 71.581.532 doğrulanmış COVID-19 vakası bildirmiştir. Türkiye'de ise bu rakam aynı tarih itibariyle 1.052.007 doğrulanmış vaka ve 16.646 ölüme ulaşmıştır (WHO, 2020). Dolayısıyla ülkeler yoğun bir biçimde bu sürecin olumsuz etkilerinden kurtulmanın yollarını aramaya başlamıştır.

Virüsün insanlar arasında hızlı ve kolayca yayılabilmesi, hükümetleri, bazı önlemler almaya zorlamıştır. Ülkelerin sınırlarını kapatmaları, ülke içi seyahatlere kısıtlamaların getirilmesi, insanların bir arada oldukları sosyal faaliyetlerin yasaklanması, çalışan kişilerin evden çalışmaları bu önlemler arasındadır. (Birleşmiş Milletler Kalkınma Programı [UNDP] Türkiye, 2020). Ayrıca insandan insana temasın olabileceği yerler kapatılmış, eğitim kurumları da bu yasaklardan nasibini almış, okullar ve üniversiteler de kapatılmıştır (Bozkurt, Jung, Xiao, Vladimirschi, Schuwer, Egorov, Paskevicius, 2020; Gupta ve Goplani, 2020). Eğitim kurumlarının kapatılması ve yüz yüze eğitime ara verilmesiyle dünyada tüm eğitim düzeylerinden öğrenci nüfusunun yaklaşık yarısına karş11ı gelen 1,6 milyar öğrencinin eğitimi kesintiye uğramıştır (UNESCO, 2020; UNICEF, 2020). Kesintiye uğrayan eğitime destek olmak adına, Türkiye'de Millı̂ Eğitim Bakanlığı tarafından 23 Mart 2020 tarihinde EBA (Eğitim Bilişim Ağı) ile internet üzerinden ve televizyon ekranlarından gerekli telafi eğitimi desteği sunulmaya başlanmıştır (Duban ve Şen, 2020). 
Öte yandan bu çalışmaya konu olan bilişsel yapı "bellekteki kavramlar arasındaki ilişkileri ifade eden hipotetik yapı" olarak tanımlanmaktadır (Tongaç, 2006). Bireylerin sahip olduğu bilişsel yapıların; bilgilerin anlamlı hale getirilmesinde, birbirleri arasında ilişki kurulmasında ve istenildiğinde geri getirilmesinde önemli bir yeri sahip olduğu bilinmektedir (Uçak ve Güzeldere, 2006; Ceylan, 2015). Kavramların soyut veya gözle görünür olmaması, olaylar, varlıklar ve nesnelerle ilgili geçirilen yaşantılar sonucu insan zihninde şekillendiği bilinmektedir (Knippels, Waarlo ve Boersma, 2005; Quınn, Pegg ve Panızzon, 2009; Çepni, 2012). Kavramlarla ilgili zayıf bilişsel yapıların ise yeni bilgilerin bellekte işlenmesi sürecinde olumsuzluklara sebep olacağı belirtilmektedir (Ioannides ve Vosniadou, 2001; Tsai ve Huang, 2002). Oysa bilişsel yapıdaki kategori sayısının fazla olması bu kategoriler arasındaki kurulan ilişki sayısını artırmakta ve bireyin bilgiyi algılamasını ve ilintiyi kurmasını kolaylaştırmaktadır (Uçak ve Güzeldere, 2006). Çünkü bir şeyin algılanması bireyin sosyal yaşamında o şeye yüklenen anlamaları içerir ve insanlar çevrelerinde olup biten her şeyi ilgilerinin, düşüncelerinin, yaşlarının, eğitim seviyelerinin, yaşam çevrelerinin, değerlerinin vb. etkisiyle çok farklı şekillerde algılayabilirler (Beyoğlu, 2015; Kaleli Yılmaz ve Güven, 2015).

Diğer taraftan mikroskobik canlılar, virüs, grip konuları öğrencilerin bilişsel yapı oluşturmakta oldukça zorlandığı konulardandır (Uzunkaya, 2007; Dumais ve Hasni, 2009; Karadon ve Şahin, 2010. Kurt ve Ekici, 2013; Gürler ve Önder, 2014; Töman ve Çeker, 2019; Takmaz ve Yılmaz 2020). İlkokul 4. sınıf öğrencileri ile yapılan bir çalışmada öğrencilerin mikroorganizmaların özellikleri ile ilgili oldukça fazla kavram yanılgısına sahip olduğu belirlenmiştir (Töman ve Çeker, 2019). Üstelik ilkokul düzeyinde verilen fen bilimleri dersinin pek çok konusunun bu çalışmaya konu olan Covid 19 kavramı kapsamındaki mikroorganizmalar konusu ile doğrudan ya da dolaylı olarak ilişkili olduğu bilinmektedir (MEB, 2018). Bu noktalar tüm dünyayı tehdit eden Covid-19 kavramına ilişkin ilkokul 3. ve 4. sınıf sahip olduğu bilişsel yapıları önemli hale getirmektedir.

İlgili literatür incelendiğinde tüm dünyada etkisini gösteren COVID-19 pandemisi ile ilgili eğitim alanında yapılan çalışmaların sınırlı olduğu, yapılan çalışmaların öğretmen ve öğretmen adayları ile yürütüldüğü, uzaktan eğitime ve Covid 19 süreci hakkında genel görüş almaya odaklandığ1 belirlenmiştir (Bayburtlu, 2020; Duban ve Şen, 2020; Görgülü Arı ve Hayır Kanat, 2020; Karahan, Bozan ve Akçay, 2020). Bunun yanı sıra Dönmez ve Gürbüz (2020) tarafından 112 ön lisans ve lisans öğrencisi yapılan bir çalışmada ise üniversite öğrencilerinin kavram hakkındaki bilişsel yapıları araştırılmıştır. Çalışmada katılımcıların Covid-19 kavramı ile ilgili 11 farklı bilişsel yapıya sahip oldukları belirlenirken en zengin bilişsel yapının algı, bulaşma nedeni ve korunma yolları üzerinde yoğunlaştığı belirtilmiştir. Literatür de konu ile ilgili ilköğretim öğrencileriyle yürütülen tek çalışmaya rastlanmıştır. Sirem ve Baş (2020)'a ait olan bu çalışmada, ilkokul öğrencilerinin Covid-19 sürecinde uzaktan eğitim deneyimlerinin araştırılması amaçlanmış ve çalışma sonucunda uzaktan eğitim sürecinin öğrencilere faydalı olduğu ve okumalarına katkı sağladığı belirlenmiştir. Diğer taraftan hayatımızın 
merkezine oturan Covid-19 kavramına ilişkin, çocukların geliştirdikleri bilişsel yapılarını araştırmaya yönelik bir çalışmaya ise literatürde rastlanmamıştır. Bu yönde yapılacak bir çalışmadan elde edilecek sonuçların başta öğretmenler olmak üzere veliler ve program yapıcılar gibi farklı kesimlere fayda sağlayacağı düşünülmektedir. Yukarıda değinilen noktalardan hareketle bu çalışmanın amacı "ilkokul 3. ve 4. sınıf öğrencilerinin Covid-19 kavramına ilişkin bilişsel yapılarının incelenmesi” olarak belirlenmiştir.

\section{YÖNTEM}

$\mathrm{Bu}$ çalışmada tarama modeli kullanılmıştır. Tarama modelinde katılımcıların bir konuya ya da olaya ilişkin görüş, ilgi, beceri, yetenek, tutum vb. özellikleri, sorulara verilen cevaplardan elde edilmektedir. (Büyüköztürk, Kılıç Çakmak, Akgün Özcan, Karadeniz ve Demirel, 2018). Literatürde yaygın kullanılan ve büyük gruplar üzerinde çalışma olanağı veren tarama çalışmaları, araştırmacının bağımsız değişken üzerinde herhangi bir müdahalesinin olmadığı ve geçmişte ya da halen var olan bir durumun var olduğu şekliyle betimlenmesini amaçlayan araştırmalardır (Karasar, 2012; Büyüköztürk, 2012a). Bu araştırmada da öğrencilerin Covid-19 kavramına ilişkin bilişsel yapıları ortama herhangi bir müdahale yapılmadan olduğu gibi yansıtılmak istendiğinden tarama modeli kullanılması tercih edilmiştir.

\section{Örneklem}

Bu çalışma Doğu Anadolu bölgesindeki bir ilin merkezinde bulunan bir ilkokulun öğrencileri ile yürütülmüştür. Çalışma içinde bulunulan pandemi sürecinden dolayı uygun örnekleme yöntemi kullanılarak belirlenen öğrenciler ile yürütülmüştür. Uygun veya elverişli örnekleme; araştırmaya hız kazandıran bir yöntem olup, araştırmacının, yakın ve erişilmesi kolay olan bir örneklemi seçmesi üzerine kuruludur. Bu örnekleme yöntemi çoğu zaman araştırmacının diğer örnekleme yöntemlerini kullanma olanağının olmadığı durumlarda kullanılır (Büyüköztürk, 2012b; Kılıç, 2013). Çalışmanın örneklemini 3.sınıf düzeyinden 86 ve 4 .sınıf düzeyinden 77 öğrenci olmak üzere toplam 163 öğrenci oluşmaktadır.

\section{Veri Toplama Araçları}

$\mathrm{Bu}$ çalışmada çizme yazma tekniğinden yararlanılmıştır. Bu teknik, araştırma sorusu ya da bir temayı açıklamak amacıyla çocuğun bir resim çizmesini içeren, nitel bir veri toplama tekniğidir (Bradding ve Horstman, 1999). Literatürde farklı kademelerdeki öğrencilerin kavramlar hakkında sahip oldukları bilişsel yapılarını belirlemede çizme yazma tekniği sıklıkla kullanılmaktadır (Çetin, Özarslan, Işık ve Eser, 2012; Işsk ve Çetin, 2014; Eser, Çetin, Özarslan ve Işık, 2015). Bu tekniğin amacı öğrencide gizli kalmış fikir, bilgi ve inanışları, öğrenciyi kelimelerle sınırlamadan ortaya çıkarmaktır (White ve Gunstone, 1992). Ancak bu tekniğin analizinde ve ortaya çıkan bulguların yorumlanmasında güçlükler görülebilmektedir. Bu durumun önlenmesi için çizimlerin açıklamalarla desteklenmesi önerilmektedir. Bu yüzden bireylerin kavramla ilgili görüşlerinin açığa çıkarılmasında çizim ve açıklamalarının beraber 
kullanıldığı çizme-yazma tekniğine literatürde sıklıkla rastlanmaktadır (Çetin, vd. 2012; Işık ve Çetin, 2014; Eser, vd., 2015). Çalışmada literatür taraması yapılarak çizme yazma tekniği kullanılan çalışmalar (Çetin vd. 2012; Knowles, Parnell, Stratton ve Ridgers, 2013; Taneri ve Demir, 2013; Yalçın ve Erginer, 2014; Işık ve Çetin, 2014; Eser, vd., 2015) incelenmiş, veri toplama aracının geliştirilmesinde bu çalışmalardan faydalanılmıştır. Veri toplama aracı geliştirilirken iki sınıf öğretmeni ve bir hemşirelik yüksekokulu öğretim elemanından uzman görüşü alınmıştır. Çalışma okulların kapalı olduğu ve uzaktan eğitimin devam ettiği bir süreçte toplanmıştır. Bu süreçte öğrencilerin öğretmenleri ile görüşülmüş çalışma hakkında bilgi verilmiştir. Çalışmanın verileri "Covid 19 denilince aklınıza geliyor? Çizip birkaç cümle ile açıklayınız" cümlesi kapsamında elde edilmiş veriler whatsapp üzerinden toplanmıştır.

\section{Verilerin Analizi}

Çalışmanın verileri içerik analizi kullanılarak analiz edilmiştir. İçerik analizinde temel amaç toplanan verileri açıklayabilecek kavramlara ve ilişkilere ulaşmaktır (Yıldırım ve Şimşek, 2005; Yıldırım ve Şimşek, 2011). Bu amaçla toplanan veriler öncelikle kavramsallaştırılır, sonra ortaya çıkan kavramlara göre mantıklı biçimde organize edilerek veriyi en iyi açıklayan temalar saptanır (Yıldırım ve Şimşek, 2005). Bu çalışmada da birbirine benzeyen veriler belirli tema ve alt temalar çerçevesinde bir araya getirilmiş ve bunlar okuyucunun anlayabileceği şekilde düzenlenerek yorumlanmıştır. Çalışmada analizler yapılırken öncelikle öğrenciler sınıf düzeyleri dikkate alınarak numaralandırılmış (3.sınıf 44 kodlu öğrenci: Ö3-44 ve 4.sınıf 21 kodlu öğrenci Ö4-21 olacak şekilde) sonrasında her katılımcının çizimleri ve açıklamaları ayrı ayrı değerlendirilmiştir. Daha sonra her sınıf düzeyine ait elde edilen verilerin analizinden oluşturulan tema ve alt temalara ait frekanslar hesaplanarak tablolar oluşturulmuştur. Çalışmada öğrencilerin kavrama dair çizimlerinden ve açılamalarından elde edilen veriler kendi içerisinde çoğu kere birden çok kategori kapsamında değerlendirilmiştir. Ayrıca sadece çizim yapan açıklama yapmayan bazı öğrencilerin çizimlerinden elde edilen verilerde çalışmaya dahil edilmiştir. Çalışmada katılımcılardan elde edilen bazı örnek çizimler ve açıklamalar öğrenci kodları ve sınıf düzeyleri ile birlikte bulgular bölümünde okuyucuya sunulmuştur. Elde edilen veriler yüksek lisans yapan bir sınıf öğretmeni, alanda uzman bir öğretim üyesi ve bir sınıf öğretmeni ile birlikte çalışılarak analiz edilmiştir. Ortak bir görüşe varılamayan noktalarda tartışmalar sürdürülmüş, oluşturulan kategoriler yeniden gözden geçirilerek ortak bir karara varılmaya çalışılmıştır. Çalışmadan elde edilen verilerin analizinin güvenirliği; Güvenirlik = Görüş Birliği / (Görüş Birliği + Görüş Ayrıllğı) formülü kullanılarak hesaplanmıştır (Miles ve Huberman, 1994). Araştırmadan elde edilen çizim verilerinin analizinde kodlayıcılar arasındaki ortalama güvenirlik \%84 açıklamalarda ise \%96 olarak bulunmuştur. Güvenirlik hesaplarının \%70'in üzerinde olması durumunda araştırma güvenilir olarak kabul edilmektedir (Miles ve Huberman, 1994). 


\section{BULGULAR}

Çalışmanın bu bölümünde; Covid 19 kavramına ilişkin 3. ve 4. sınıf öğrencilerinden elde edilen verilerin belirli tema ve alt temalar çerçevesinde analiz edilmesiyle ulaşılan bulgulara yer verilmiştir. Çalışmada öğrencilerin çizimleri ve açıklamaları her sınıf düzeyi için ayrı ayrı analiz edilerek elde edilen bulgular iki farklı tabloda toplanmıştır. Bu bölümde ayrıca farklı temalar kapsamında değerlendirilen örnek çizim ve açıklamalar öğrenci kodları kullanılarak okuyucuya sunulmuştur.

Aşağıda yer alan Tablo 1'de 3. ve 4. sınıf öğrencilerinin Covid 19 kavramına ilişkin çizimlerinin analizinden elde edilen tema ve alt temalara yer verilmiştir.

Tablo 1. Öğrencilerin Covid 19 kavramına ilişkin çizimlerinin analizinden elde edilen bulgular

\begin{tabular}{|c|c|c|c|c|c|}
\hline Tema & Alt Tema & 3.sinıf & Toplam & 4.sınıf & Toplam \\
\hline \multirow{18}{*}{$\begin{array}{l}\text { Covid 19'dan } \\
\text { korunma }\end{array}$} & Maske/maske takma & 32 & \multirow{18}{*}{99} & 39 & \multirow{18}{*}{85} \\
\hline & Sosyal mesafe & 19 & & 18 & \\
\hline & Evde kalmak & 8 & & 9 & \\
\hline & Kolonya & 8 & & 2 & \\
\hline & El yıkama & 6 & & 2 & \\
\hline & Sabun & 6 & & 1 & \\
\hline & Dezenfektan & 2 & & 5 & \\
\hline & $\mathrm{Su}$ & 4 & & 3 & \\
\hline & Mendil & 4 & & 1 & \\
\hline & Siv1 sabun & 3 & & - & \\
\hline & Eldiven takma & 2 & & 1 & \\
\hline & Siperlik & 2 & & - & \\
\hline & Tokalaşmama & - & & 2 & \\
\hline & Dengeli beslenme & - & & 1 & \\
\hline & Havalandırma & 1 & & - & \\
\hline & Banyo yapmak & 1 & & - & \\
\hline & $\begin{array}{l}\text { Toplumdan izole } \\
\text { yaşam }\end{array}$ & 1 & & - & \\
\hline & Diş firçası ve macunu & - & & 1 & \\
\hline \multirow{4}{*}{$\begin{array}{l}\text { Covid 19'un } \\
\text { sebebi }\end{array}$} & $\begin{array}{l}\text { Covid } 19 \text { virüsü } \\
\text { benzeri şekil }\end{array}$ & 35 & \multirow{4}{*}{53} & 41 & \multirow{4}{*}{51} \\
\hline & Yüz şekli & 16 & & 8 & \\
\hline & Yuvarlak & - & & 2 & \\
\hline & Nokta şeklinde & 2 & & - & \\
\hline \multirow{6}{*}{ Covid 19 sonuçları } & Covid olma & 10 & \multirow{4}{*}{10} & 13 & \multirow{4}{*}{20} \\
\hline & Ölüm & - & & 5 & \\
\hline & Tabut & - & & 1 & \\
\hline & Mezartaşı & - & & 1 & \\
\hline & Hastane & 4 & & 7 & \\
\hline & Ambulans & - & & 6 & \\
\hline
\end{tabular}




\begin{tabular}{|c|c|c|c|c|c|}
\hline \multirow{6}{*}{$\begin{array}{l}\text { Covid 19'un } \\
\text { tedavisi }\end{array}$} & Sedye & - & \multirow{6}{*}{8} & 4 & \multirow{6}{*}{21} \\
\hline & Kalp monitörü & - & & 2 & \\
\hline & Serum & 2 & & - & \\
\hline & İğne & 2 & & - & \\
\hline & Hastane Covid servisi & - & & 1 & \\
\hline & Covid 19 savaş & - & & 1 & \\
\hline \multirow{8}{*}{$\begin{array}{l}\text { Covid 19'un } \\
\text { bulaştığ yerler }\end{array}$} & Düğünler & 4 & \multirow{8}{*}{13} & 1 & \multirow{8}{*}{5} \\
\hline & Sokak & 3 & & 2 & \\
\hline & $\begin{array}{l}\text { Bulaşma yeri olarak } \\
\text { hastane }\end{array}$ & 2 & & - & \\
\hline & Pazar yeri & 2 & & - & \\
\hline & Alışveriş poşeti & - & & 1 & \\
\hline & Kapı kolu & 1 & & - & \\
\hline & Para & 1 & & - & \\
\hline & Çöp kovaları & - & & 1 & \\
\hline \multirow{4}{*}{$\begin{array}{l}\text { Covid } 19 \text { ile ilgili } \\
\text { duyuşsal ifadeler }\end{array}$} & Sevinçli korona virüs & - & \multirow{4}{*}{4} & 5 & \multirow{4}{*}{11} \\
\hline & Üzüntü & 1 & & 3 & \\
\hline & Korku & 3 & & 1 & \\
\hline & Üzüntülü korona virüs & - & & 2 & \\
\hline \multirow{4}{*}{$\begin{array}{l}\text { Covid 19'un } \\
\text { bulaşma yolları }\end{array}$} & $\begin{array}{l}\text { Sosyal mesafeye } \\
\text { uymama }\end{array}$ & - & \multirow{4}{*}{3} & 5 & \multirow{4}{*}{10} \\
\hline & Önlem almama & - & & 3 & \\
\hline & $\begin{array}{l}\text { Hapşırırken ağzı } \\
\text { kapamama }\end{array}$ & 1 & & 2 & \\
\hline & $\begin{array}{l}\text { Yakın mesafeden } \\
\text { konuşma }\end{array}$ & 2 & & - & \\
\hline \multirow{3}{*}{ Covid 19 belirtileri } & Öksürme & 2 & \multirow{3}{*}{2} & - & \multirow{3}{*}{4} \\
\hline & Hapşırma & - & & 2 & \\
\hline & Terleme & - & & 2 & \\
\hline \multirow{3}{*}{$\begin{array}{l}\text { Covid 19'un } \\
\text { vücuda giriş } \\
\text { yerleri }\end{array}$} & Göz & - & \multirow{3}{*}{-} & 2 & \multirow{3}{*}{6} \\
\hline & Burun & - & & 2 & \\
\hline & Ağglz & - & & 2 & \\
\hline $\begin{array}{l}\text { Covid 19'un } \\
\text { yayilma durumu }\end{array}$ & Dünya & 2 & 2 & 2 & 2 \\
\hline Toplam & $\begin{array}{l}\text { 3-34 alt tema, } 4-43 \text { alt } \\
\text { tema }\end{array}$ & 194 & & 215 & \\
\hline
\end{tabular}

Tablo 1 incelendiğinde; öğrencilerin Covid 19 kavramına ilişkin çizimlerinin analizinden 10 tema elde edildiği görülmektedir. Bunlar sırasıyla; "Covid 19'dan korunma”, "Covid 19'un sebebi”, "Covid 19 sonuçları", "Covid 19'un tedavisi”, "Covid 19'un bulaştığı yerler", "Covid 19 ile ilgili duyuşsal ifadeler", "Covid 19'un bulaşma yolları", "Covid 19 belirtileri”, "Covid 19'un vücuda giriş yerleri”, "Covid 19'un yayılma durumu” şeklindedir. Çalışmada 3.sınıf öğrencilerinin bu temalara ilişkin çizimlerinden elde edilen alt tema sayısı 34 iken bu alt temaların toplam frekansı 194 olarak 
belirlenmiştir. 4.sınıf öğrencilerinin ise belirlen temalardan 43 alt tema ürettiği ve toplam frekanslarının 215 olduğu görülmektedir. Bu temalardan en yüksek frekansa sahip olan "Covid 19'dan korunma" temasıdır. Bu temanın üçüncü sınıflardaki frekansı 99 iken dördüncü sınıflardaki frekansının 85 olduğu görülmektedir. Tema kapsamında 18 alt tema bulunurken bu temalar arasında en yüksek frekansa sahip olan "Maske/maske takma” alt temasının üçüncü sinıflarda 32, dördüncü sınıflarda 39 frekansa sahip olduğu tespit edilmiştir. Çalışmadan elde edilen en yüksek frekansa sahip ikinci tema "Covid 19'un sebebi" temasıdır. Dört alt temaya sahip olan bu temanın üçüncü sınıflardaki frekansı 53 iken dördüncü sınıflardaki frekans1 51'dir. Bu tema içerisinde değerlendirilen en yüksek frekansa sahip "Covid 19 virüsü benzeri şekil" alt temasının ise üçüncü sınıflarda 35, dördüncü sınıflarda 41 frekansa sahip olduğu görülmektedir. "Covid 19 sonuçları" teması bu çalışmadan elde edilen üçüncü en yüksek frekansa sahip temadır. Dört alt temaya sahip olan bu temanın üçüncü sınıflardaki frekans1 10 iken dördüncü sınıflardaki frekansı 20'dir. Bu tema içerisinde olduğu değerlendirilen en yüksek frekansa sahip "Covid olma” alt temasının üçüncü sınıflarda 10, dördüncü sınıflarda 13 frekansa sahip olduğu belirlenmiştir. Sadece dördüncü sınıf öğrencilerinin çizimlerinde rastlanan "Ölüm” alt temasının frekansı 5 iken ve "Tabut" ve "Mezartaşı" ifadelerin birer frekansa sahip olduğu belirlenmiştir. Çalışmadan elde edilen “Covid 19'un tedavisi” temasının en yüksek frekansa sahip dördüncü tema olduğu görülmektedir. Sekiz alt temaya sahip olan bu temanın üçüncü sınıflardaki frekans1 8 iken, dördüncü sınıflardaki frekans1 21 'dir. Bu tema içerisinde değerlendirilen en yüksek frekansa sahip "Hastane” alt temasının ise üçüncü sınıflarda 4, dördüncü sınıflarda 7 frekansa sahip olduğu görülmektedir. Sadece dördüncü sınıf öğrencilerinin çizimlerinde rastlanan "Hastane Covid servisi" alt temasının frekansının ise 1 olduğu belirlenmiştir.

Çalışmada öğrenci çizimlerinin analizinden elde edilen tablo 1 incelendiğinde "Covid 19'un bulaşttğı yerler" temasının toplam frekansı 18 iken "Covid 19 ile ilgili duyuşsal ifadeler" temasının toplam frekans1 15 olduğu görülmektedir. Sekiz alt temaya sahip olan "Covid 19'un bulaşttğı yerler" temasının üçüncü sınıflardaki frekansı 13, dördüncü sınıflardaki frekansı 5 olarak belirlenmiştir. $\mathrm{Bu}$ temada en yüksek frekansa sahip alt temalar "Dügünler", "Sokak", "Bulaşma yeri olarak hastane", "Pazar yeri" alt temalanıdır. Tablo 1'de "Covid 19 bulaşma yolları" temasının toplam 13 frekansa sahip olduğu görülmektedir. Bu temanın alt temalarından "Sosyal mesafeye uymama" alt teması 5 frekansa sahipken bunu "Önlem almama", "Hapşırırken ăgzı kapamama", "Yakın mesafeden konuşma" izlemektedir. "Covid 19 belirtileri" ve "Covid 19'un vücuda giriş yerleri”" temaları ise bu çalışmadan elde edilen 6 frekansa sahip temalardır. Çalışmada "Covid 19'un vücuda giriş yerleri” temasına sadece dördüncü sınıflarda rastlanmıştır. "Covid 19'un yayılma durumu” temasının ise 4 frekans ile çalışmadan elde edilen en düşük frekansa sahip tema olduğu Tablo 1'den görülmektedir.

Öğrencilerin Covid 19 kavramına ilişkin çizimlerinden birkaç örnek öğrenci kodları ve sınıf düzeyleri ile birlikte aşağıda okuyucuya sunulmuştur. 

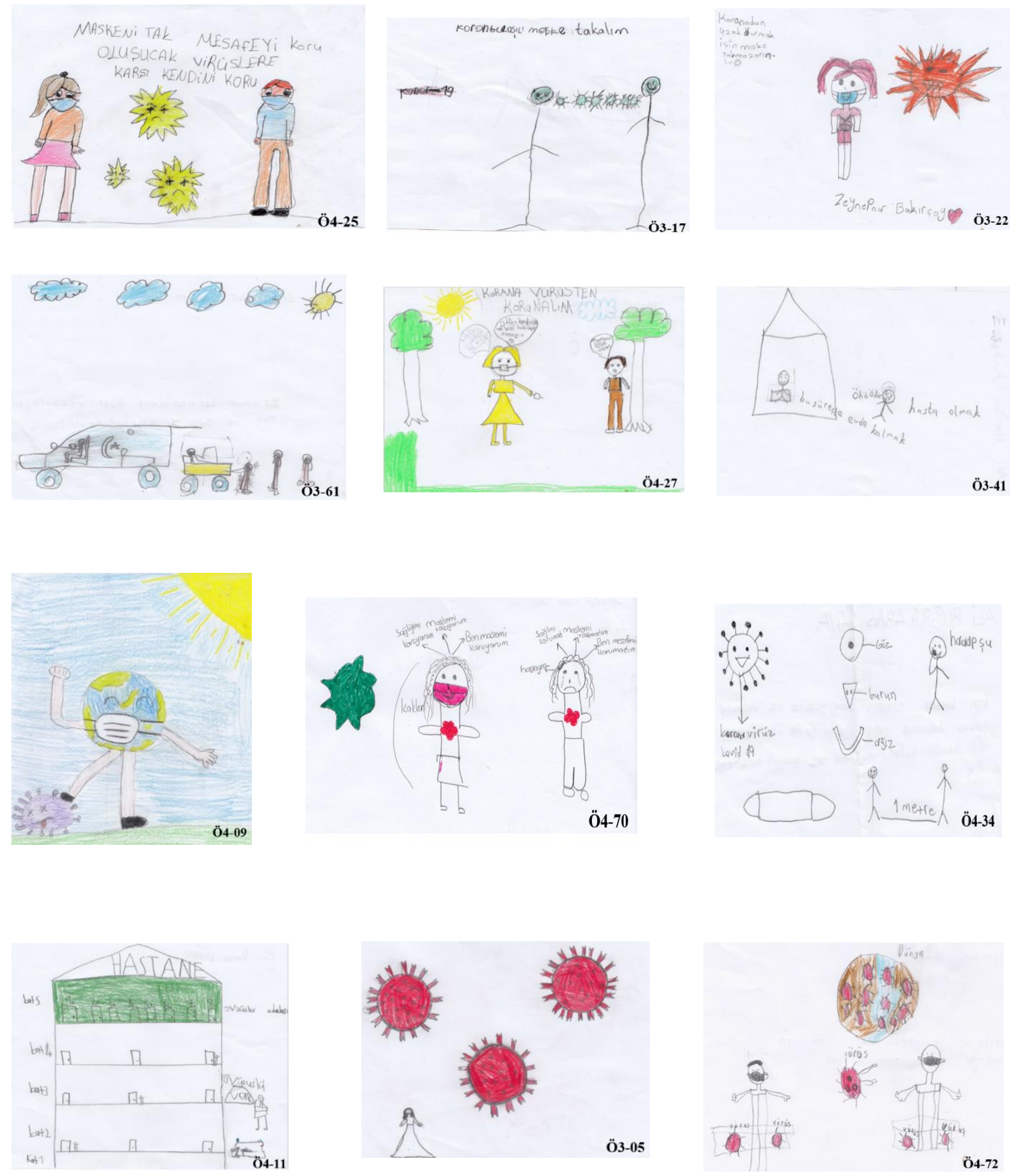

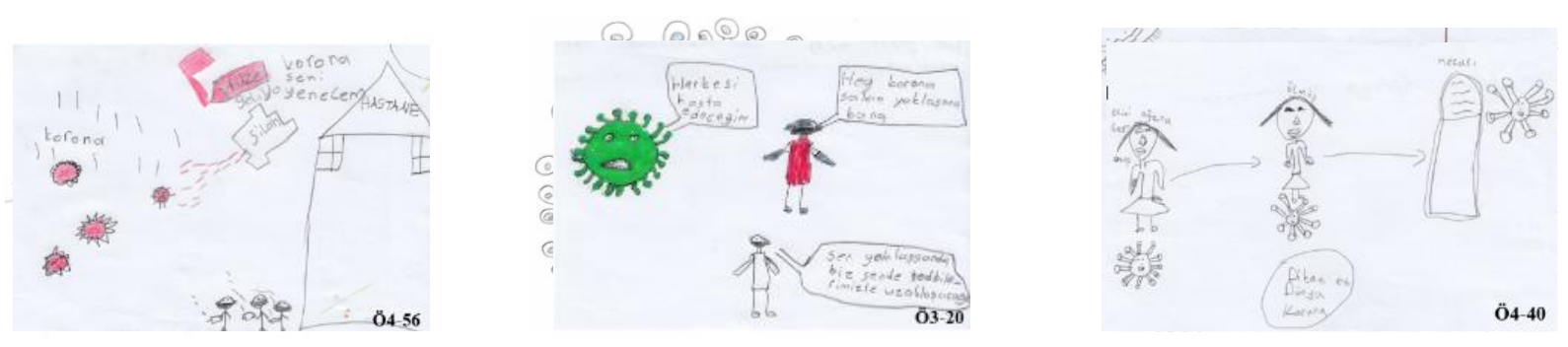

Aşağıda yer alan Tablo 2'de 3. ve 4. sınıf öğrencilerinin Covid 19 kavramına ilişkin açıklamalarının analizinden elde edilen tema ve alt temalara yer verilmiştir.

Tablo 2. Öğrencilerin Covid 19 kavramına ilişkin açıklamalarının analizinden elde edilen bulgular

\begin{tabular}{|c|c|c|c|c|c|}
\hline Tema & Alt tema & 3.sinıf & Toplam & 4.sinıf & Toplam \\
\hline \multirow{27}{*}{$\begin{array}{l}\text { Covid 19'dan } \\
\text { Korunma }\end{array}$} & Maske / Maske takmak & 33 & \multirow{27}{*}{122} & 29 & \multirow{27}{*}{110} \\
\hline & Sosyal mesafe & 21 & & 18 & \\
\hline & El yıkamak & 19 & & 20 & \\
\hline & $\begin{array}{l}\text { Dezenfektan/Dezenfektan } \\
\text { kullanmak }\end{array}$ & 8 & & 6 & \\
\hline & Evde kalmak & 7 & & 5 & \\
\hline & Kolonya & 7 & & 3 & \\
\hline & Sabun/Sabun kullanmak & 5 & & 2 & \\
\hline & Eldiven / Eldiven takmak & 4 & & 3 & \\
\hline & Hijyen kuralları uymak & - & & 6 & \\
\hline & Islak Mendil kullanmak & 2 & & 2 & \\
\hline & Tedbir almak & 1 & & 3 & \\
\hline & Dişarı ç1kmama & 3 & & 1 & \\
\hline & Sebze meyve yemek & 3 & & - & \\
\hline & Sağlıklı beslenme & - & & 3 & \\
\hline & İyi uyku uyumak & 2 & & - & \\
\hline & Spor yapmak & 2 & & - & \\
\hline & Tokalaşmama & 1 & & 1 & \\
\hline & $\mathrm{Su}$ & 1 & & 1 & \\
\hline & Özel eşyaları ayırmak & - & & 1 & \\
\hline & Elleri 20 sn. yıkamak & - & & 1 & \\
\hline & $\begin{array}{l}\text { Mikroplu şeyleri elimize } \\
\text { almamak }\end{array}$ & - & & 1 & \\
\hline & Hapşırırken ağzını kapamak & - & & 1 & \\
\hline & Öksürürken ağzını kapamak & - & & 1 & \\
\hline & Uyarı yapmak & - & & 1 & \\
\hline & Kurallara uymak & - & & 1 & \\
\hline & Sivı tüketmek & 1 & & - & \\
\hline & Sağlığımızı korumak & 1 & & - & \\
\hline
\end{tabular}




\begin{tabular}{|c|c|c|c|c|c|}
\hline & Pencere açmak & 1 & & - & \\
\hline \multirow{5}{*}{$\begin{array}{l}\text { Covid 19'un } \\
\text { Sebebi }\end{array}$} & Virüs & 8 & \multirow{5}{*}{20} & 8 & \multirow{5}{*}{11} \\
\hline & Covid virüsü/Covid 19 & 7 & & 2 & \\
\hline & Mikrop & 3 & & - & \\
\hline & Mikroorganizmalar & 2 & & - & \\
\hline & Bakteri & - & & 1 & \\
\hline \multirow{3}{*}{$\begin{array}{l}\text { Covid 19’un } \\
\text { Özellikleri }\end{array}$} & Bulaşıc1 olma & 5 & \multirow{3}{*}{6} & 12 & \multirow{3}{*}{14} \\
\hline & Yayılma & 1 & & 1 & \\
\hline & Ölümcül olma & - & & 1 & \\
\hline \multirow{2}{*}{$\begin{array}{l}\text { Covid 19'un } \\
\text { Sonuçları }\end{array}$} & Covid olma & 11 & \multirow[t]{2}{*}{16} & 2 & \multirow[t]{2}{*}{3} \\
\hline & Ölüm & 5 & & 1 & \\
\hline \multirow{6}{*}{$\begin{array}{l}\text { Covid 19'un } \\
\text { Bulaştığ } 1 \text { Yerler }\end{array}$} & Düğün & 1 & \multirow{6}{*}{6} & 3 & \multirow{6}{*}{7} \\
\hline & Sokak & 1 & & 2 & \\
\hline & Hastane & 1 & & 1 & \\
\hline & Pazar yeri & 2 & & - & \\
\hline & Bina kap1 kolu & - & & 1 & \\
\hline & Otobüs & 1 & & - & \\
\hline \multirow{6}{*}{$\begin{array}{l}\text { Covid } 19 \text { ile } \\
\text { İlgili } \\
\text { Duyuşsal } \\
\text { ifadeler }\end{array}$} & Okula özlem & 3 & \multirow{6}{*}{7} & 1 & \multirow{6}{*}{6} \\
\hline & $\begin{array}{l}\text { Virüsü pis yaratık-hastalık } \\
\text { olarak nitelendirme }\end{array}$ & 1 & & 2 & \\
\hline & Korkmak & 1 & & 1 & \\
\hline & Virüsten nefret etmek & - & & 1 & \\
\hline & Üzülmek & 1 & & 1 & \\
\hline & Kötü hissetme & 1 & & - & \\
\hline \multirow{3}{*}{$\begin{array}{l}\text { Covid 19'un } \\
\text { Tedavi Edildiği } \\
\text { Yerler }\end{array}$} & Hastane & 3 & \multirow{3}{*}{3} & 4 & \multirow{3}{*}{7} \\
\hline & Ambulans & - & & 2 & \\
\hline & Sedye & - & & 1 & \\
\hline \multirow{3}{*}{$\begin{array}{l}\text { Covid 19'un } \\
\text { Vücuda Giriş } \\
\text { Yerleri }\end{array}$} & Göz & - & \multirow{3}{*}{-} & 2 & \multirow{3}{*}{6} \\
\hline & Burun & - & & 2 & \\
\hline & Ağız & - & & 2 & \\
\hline \multirow{3}{*}{$\begin{array}{l}\text { Covid 19’un } \\
\text { Belirtileri }\end{array}$} & Nefes alamama & 1 & \multirow{3}{*}{3} & - & \multirow{3}{*}{-} \\
\hline & Öksürük & 1 & & - & \\
\hline & Grip & 1 & & - & \\
\hline \multirow{2}{*}{$\begin{array}{l}\text { Covid } 19 \\
\text { Yaptırımları }\end{array}$} & 15 günlük karantina & 1 & \multirow[t]{2}{*}{2} & 1 & \multirow[t]{2}{*}{1} \\
\hline & Para cezası & 1 & & - & \\
\hline Toplam & 3. sinif, 43 alt tema -4 . Sin 1 & & 185 & & 165 \\
\hline
\end{tabular}

Tablo 2 incelendiğinde; öğrencilerin Covid 19 kavramına ilişkin açıklamalarından 10 farklı tema elde edildiği görülmektedir. Bunlar sırasıyla; "Covid 19'dan korunma”, "Covid 19'un sebebi”, "Covid 19'un özellikleri" "Covid 19'un sonuçları", "Covid 19'un bulaştı̆̆ yerler”, "Covid 19 ile ilgili duyuşsal ifadeler", "Covid 19'un tedavi edildiği yerler", "Covid 19'un vücuda giris yerleri”, "Covid 19 belirtileri", "Covid 19 yaptırımları" şeklindedir. Çalışmada üçüncü sınıf öğrencilerinin bu temalara 
ilişkin açıklamalarından elde edilen alt tema sayısı 43 iken bu alt temaların toplam frekansı 185 olarak belirlenmiştir. Dördüncü sınıf öğrencilerinin ise belirlen temalardan 46 alt tema ürettiği ve toplam frekanslarının 165 olduğu görülmektedir. Öğrencilerin açıklamalarından elde edilen en yüksek frekansa sahip olan "Covid 19'dan korunma” temasıdır. Bu temanın üçüncü sınıflardaki frekansı 122 iken dördüncü sınıflardaki frekansının 110 olduğu görülmektedir. Bu tema içerisinde 28 alt tema bulunurken bu temalar arasında en yüksek frekansa sahip olan "Maske/maske takma" alt temasının üçüncü sınıflarda 33 dördüncü sınıflarda 29 frekansa sahip olduğu tespit edilmiştir.

Çalışmadan elden edilen en yüksek frekansa sahip ikinci tema "Covid 19'un sebebi" temasıdır. Beş alt temaya sahip olan bu temanın üçüncü sınıflardaki toplam frekansı 20 iken dördüncü sınıflardaki toplam frekansı 11'dir. Bu tema içerisinde değerlendirilen en yüksek frekansa sahip "virüs" alt temasının ise her iki sınıf düzeyinde 8 frekansa sahip olduğu görülmektedir. Sadece dördüncü sınıf öğrencilerinin açıklamalarında rastlanan "bakteri” "alt temasının frekansının ise 1 olduğu belirlenmiştir. “Covid 19'un Özellikleri” teması bu çalışmadan elde edilen üçüncü en yüksek frekansa sahip temadır. Üç alt temaya sahip olan bu temanın üçüncü sınıflardaki frekansı 6 iken dördüncü sınıflardaki frekansı 14 'dür. $\mathrm{Bu}$ tema içerisinde olduğu değerlendirilen en yüksek frekansa sahip "Bulaşıcı olma" alt temasının üçüncü sınıflarda 5, dördüncü sınıflarda 12 frekansa sahip olduğu belirlenmiştir. Öğrencilerin kavrama ilişkin açıklamalarından elde edilen diğer temaların ise sırasıyla "Covid 19 sonuçları (19)", "Covid 19'un bulaşttğ yerler (13)”, "Covid 19 ile ilgili duyuşsal ifadeler (13)”, "Covid 19'un tedavi edildiği yerler (10)”, “Covid 19'un vücuda giriş yerleri (6)” olarak sıralandığı belirlenmiştir. Çalışmadan elde edilen "Covid 19 belirtileri" ve sadece öğrencilerin açıklamalarında rastlanan "Covid 19 Yaptırımları" temalarının ise toplam 3 frekansa sahip olduğu Tablo 2'den görülmektedir.

Aşağıda öğrencilerin Covid 19 kavramına ilişkin ve açıklamalarından birkaç örnek öğrenci kodları ve sınıf düzeyleri ile birlikte okuyucuya sunulmuştur.

\section{kotalobir batuiri}

Ö4-55

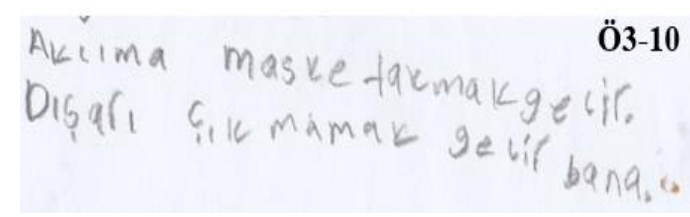

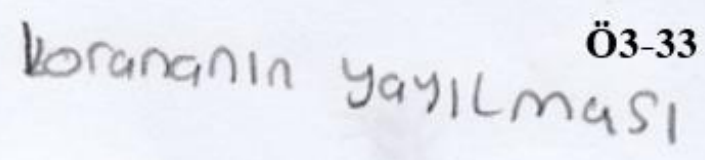

karana kedimi kötü hisederim
Ö3-19 


$$
\begin{aligned}
& \text { Mesachimizi Korulmaliyiz } \\
& \text { Maskekakmoligiz } \\
& \text { ö3-15 } \\
& \text { kerona virus denince aklima hastalik, } \\
& \text { nefessizlik ve grip ge Liyor } \\
& \text { ö3-66 }
\end{aligned}
$$$$
\text { dugunere gidersek kovonaya. }
$$$$
\text { 04-43 }
$$
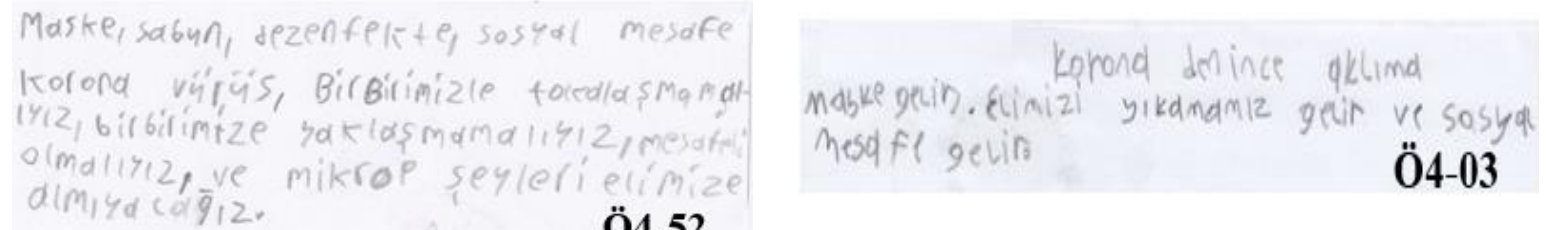

Ö4-52

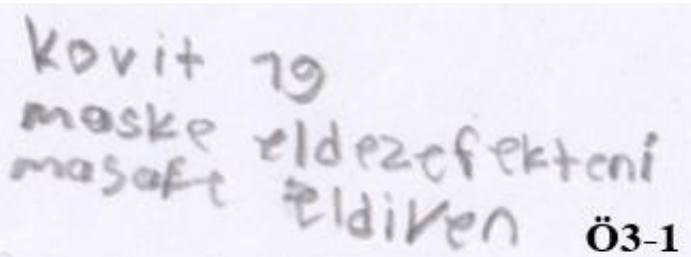

Bir ksibi bir kisue koreng bulastirms ve 15 gün karantinac Ö3-39

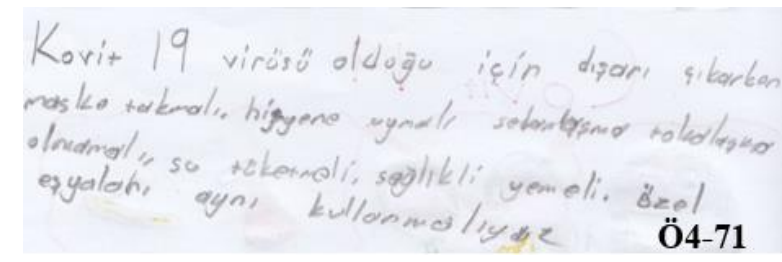

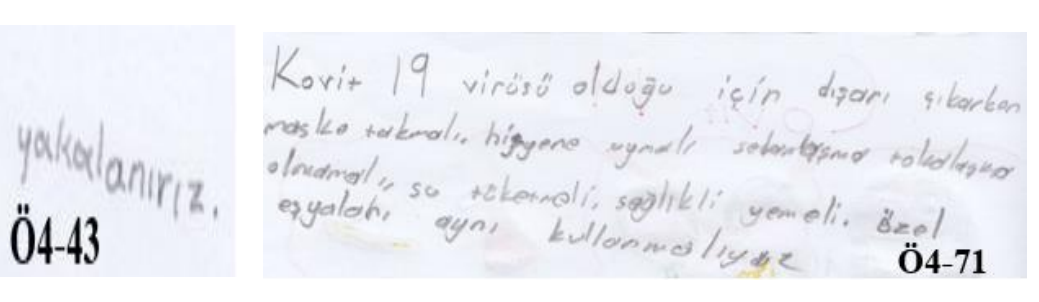

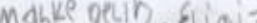
mesd fel gelin

$$
\begin{aligned}
& \text { Korona vürüs itk aiktigi zaman } \\
& \text { qok üzüldüm ögretmenimden ve } \\
& \text { arkadaslarimdan ayrilicam diye tatilde } \\
& \text { ögretmenimi ve arkadaslarimi qok } \\
& \text { ozläyorum }
\end{aligned}
$$

Korond vürús cak ydygin ve buștiricl bir hasta. liktir.

\section{Ö4-48}

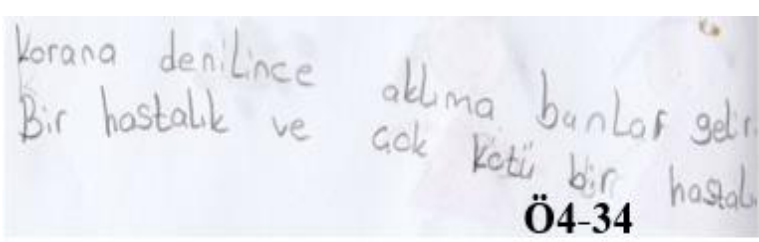

Ö3-2

\section{SONUÇLAR ve TARTIŞMA}

İlkokul 3.ve 4. sınıf öğrencilerinin Covid-19 kavramına ilişkin bilişsel yapılarının belirlenmesi amacıyla yapılan bu çalışmada; öğrencilerin çizimlerinden ve açıklamalarından 10'ar bilişsel yapı edilmiştir. Elde edilen bu bilişsel yapıların çoğu öğrencilerin çizim ve açıklamalarda ortak iken, bazılarının farklı olduğu Tablo 1 ve 2'den görülmektedir. Bu durum bazı öğrencilerin kavrama ilişkin çizimleri ile açıklamalarında farklı noktalara odaklanmalarından kaynaklanmaktadır. Çalışmada her ne kadar öğrencilerin hem çizimlerinden hem de açıklamalarından 10 bilişsel yapı elde edilmiş olsa da 
dördüncü sınıf öğrencilerinin oluşturdukları alt tema sayısının hem çizim hem açıklamalarda üçüncü sınıf öğrencilerinden daha fazla olduğu görülmektedir. Bireylerin kavramlarla ilgili algılarının; yaşlarının, eğitim seviyelerinin, yaşam çevrelerinin, vb. etkisiyle çok farklı şekillerde olabileceği belirtilmektedir (Beyoğlu, 2015; Kaleli Yılmaz ve Güven, 2015). Dolayısıyla çalışmadan elde edilen bu sonucun literatüre paralel olduğu söylenebilir.

Çalışmadan elde edilen diğer bulgulara bakıldığında; öğrencilerin önemli bir bölümünün çizimlerinde ve açıklamalarında "Covid-19'dan Korunma" teması kapsamındaki alt temalara yoğunlaşacak şekilde soruyu cevapladıkları görülmektedir. Bu tema kapsamındaki alt temaların sayısının çizimlerde 18, açıklamalarında ise 29 olduğu Tablo 1 ve 2'den görülmektedir. Bu alt temalardan "maske/maske takma" alt temasının öğrencilerin hem çizim hem de açıklamalarında en yüksek frekansa ait alt tema olduğu belirlenmiş̧tir. Bunu "sosyal mesafe" ve diğer alt temalar izlemektedir. Bu noktadan hareketle ilkokul 3.ve 4. sınıf öğrencilerinin Covid 19 kavramına ilişkin geliştirdikleri en kuvvetli bilişsel yapının "Covid-19'dan korunma” olduğu söylenebilir. Dönmez ve Gürbüz (2020) tarafindan üniversite öğrencilerinin Covid-19 virüsü hakkında bilişsel yapılarının belirlenmesi amacıyla yapılan bir çalışmada Covid-19'dan korunma yolları kategorisinin en kuvvetli ikinci bilişsel yapı olduğu ve katılımcıların sıklıkla maske, önlem, temizlik, sosyal mesafe, dezenfektan gibi hayatımıza yeni giren kavramları tekrar ettiği belirtilmektedir. Ekici ve Kurt (2014) tarafından öğretmen adaylarının AIDS ile ilgili bilişsel yapılarını tespit etmek amacıyla yapılan başka bir çalışmada da bu çalışmanın sonuçlarına benzer sonuçlara ulaşılmış, AIDS'ten korunma yollarının en kuvvetli bilişsel yapılardan biri olduğu belirlenmiştir.

Öğrencilerin kavrama ilişkin çizim ve açıklamalarından oluşturulan “Covid 19'un sebebi” teması çalışmadan elde edilen ikinci en yüksek frekansa sahip bilişsel yapıdır. Öğrenci açıklamalarında bu temanın en yüksek frekansa sahip alt teması "virüs" alt teması iken, çizimlerde en yüksek frekansa ait alt temanın "Covid 19 virüsü benzeri şekil” olduğu görülmektedir. Öğrencilerin "Covid 19 virüsü benzeri şekil" alt temasında yer alan çizimleri incelendiğinde ise tamamına yakınında hastalığa sebep olan virüsün yüzeyindeki çıkıntılara ver verdiği belirlenmiştir. Bu bulgu dikkat çekicidir. Virüsün yüzeyinde bulunan protein çıkıntılarının bu virüs ailesinin ortak bir özelliği olduğu ve bu çıkıntılar sayesinde enfekte edebileceği hücreleri belirleyerek, hücrelerdeki almaçlara bağlandığg belirtilmektedir (Sağlık Bakanlığı, 2020; Ak, 2020). Elbetteki öğrencilerin virüsün dış yüzeyindeki bu çıkıntıların görevini bütünüyle bilmesi beklenemez. Fakat öğrencilerin önemli bir bölümünün çizimlerinde bu ayrıntıya yer vermesi onların Covid 19'a neden olan virüsün şeklini genel hatları bildiklerine işaret etmektedir. Farklı medya organlarında hastalığa sebep olan virüs ve virüs özelliklerine sıklıkla yer verilmesi bu durumun temel nedeni olabilir. Ekici ve Kurt (2014) tarafindan yapılan bir çalışmada bu çalışmanın sonuçlarına benzer sonuçlara ulaşılmıştır. Kırk dört biyoloji öğretmen adayı ile yürütülen çalışmada öğretmen adaylarının virüslere ilişkin bilişsel yapılarında virüs şeklinin oldukça önemli bir 
yer tuttuğu belirlenmiştir. Çalışmada "Covid 19'un sebebi" teması kapsamında elde edilen bir diğer bulgu ise öğrencilerin çizdikleri virüs benzeri şekillere hem 3 hemde 4. sınıf düzeyinde ağız, burun, göz, el, kol eklemesidir. Değişik yaş grubundaki öğrencilerle yapılan çalışmalarda mikroorganizmaların sıklıkla çizgi film kahramanlarına benzetildiği ve yüz, el vs. eklenerek çizildiği belirtilmektedir (Choi ve Hong, 2014; Eser vd., 2015). Dolayısıyla çalışmadan elde edilen sonuçların literatürle desteklendiği söylenebilir. Diğer taraftan insan özelliklerinin diğer canlılara veya cansız nesnelere yüklenmesi olarak tanımlanan Antropomorfizm'in çocuklarda sıklıkla görüldüğü belirtilmekte ve bu fikirlerin yaşla birlikte azalma eğiliminde olsa da bazılarının değişime dirençli olduğu bildirilmektedir (Byrne, 2011). Çalışmada ayrıca "Covid 19'un sebebi" temasında bir öğrencinin hastalığının sebebi yönündeki açıklamalarında "Bakteri" ifadesine rastlanmıştır. Aynı ifadeye Ekici ve Kurt (2014) tarafından öğretmen adaylarının AİDS kavramına ilişkin geliştirdikleri bilişsel yapılar arasında da rastlandığı belirlenmiştir. Dolayısıyla çalışmadan elde edilen bu sonucun literatürle desteklendiği söylenebilir

Çalı̧̧mada öğrencilerin çizim ve açıklamalarından elde edilen en yüksek frekansa bilişsel yapılardan birinin de "Covid 19 sonuçları" olduğu belirlenmiştir. Öğrencilerin bu tema içerisindeki çizim ve açıklamalarında "Covid 19 olma" alt kategorisinin en yüksek frekansa sahip alt tema olduğu bunu ölüm mezar tabut alt temaların takip ettiği belirlenmiştir. Dolayısıyla 3. ve 4. sınıf öğrencilerinin hastalığa yakalanmayı ve ölümü Covid 19'un en önemli sonucu olarak gördükleri söylenebilir. Öte yandan ilkokul öğrencilerinin Covid 19 kavramına dair sahip oldukları bilişsel yapılarının ne yönde olduğuna ilişkin literatürde bir çalışmaya rastlanmamasına rağmen daha büyük yaş grubundaki öğrencilerinin kavramla ilgili geliştirdikleri bilişsel yapıların bu çalışmanın bulgularına benzer olduğu belirlenmiştir. Konu ile ilgili üniversite öğrencileri ile yapılan bir çalışmada hasta olmanın ve yanı sıra ölümün Covid-19 en önemli sonuçlarından biri olduğu vurgulanmıştır (Dönmez ve Gürbüz, 2020). Benzer sonuçlara öğretmen adaylarının AİDS kavramına dair geliştirdikleri bilişsel yapılar arasında da rastlanmıştır (Ekici ve Kurt, 2014).

Öğrencilerin özellikle çizimlerinde yoğunlaştığı ve açıklamalarında da yer alan bir diğer tema "Covid 19'un tedavisi” temasıdır. Bu tema kapsamındaki çizim ve açıklamalarda en yüksek frekansa sahip alt tema "Hastane” alt temasıdır Çalışmada öğrencilerin kavrama ilişkin çizim ve açıklamalarının her ikisinde de hastaneler alt temasının yer aldığı Tablo1 ve 2'den görülmektedir. Başka bir deyişle çalışmada öğrencilerin hastaneleri hem tedavi merkezleri hemde hastalığın bulaştığı yerleri olarak gördükleri belirlenmiştir. Öğrenci çizim ve açıklamalarından belirlenen bir diğer nokta ise hastalığın bulaşma yerleri arasında "Düğünler", "Sokaklar”, "Pazar yerleri”, “Kapı kolu”, "Alışveriş poşeti”, "Para" ve "Otobüs" gibi ifadelere yer verilmesidir. Bu durum çocukların konu ile ilgili farkındalık düzeylerinin yüksek olması ile açıklanabilir. Benzer şekilde öğrenci çizimlerinden elde edilen "Covid 19 'un bulaşma yollart" teması kapsamında "Sosyal mesafeye uymama", "Önlem almama", "Hapşııırken ă̆zı kapamama" "Yakın mesafeden konuşma" gibi alt temalarına rastlanmıştır. Bu 
bulgular ilkokul 3. ve 4. sınıf öğrencilerinin Covid 19 ile ilgili farkındalık düzeylerinin yüksek olduğuna dair yukarıda değinilen bulguları desteklemektedir. Çalışmada "Covid 19 belirtileri" ve "Covid 19'un vücuda giriş yerleri" temalarının alt temaları incelendiğinde, öğrencilerin kavram ile ilgili çizimlerinde ve açıklamalarında hastalığın vücuda giriş yerleri olarak ağız, burun ve göze, hastalığın belirtileri olarak öksürük, hapşırma, terleme, nefes alamama gibi ifadelere yer verdikleri görülmektedir. Ayrıca çalışmada öğrencilerin açıklamalarından elde edilen "Covid 19 Yaptırımları" bilişsel yapısının kapsamında "15 günlük karantina" ve "Para cezası" alt temalarının olduğu görülmektedir. Üniversite öğrencilerinin Covid-19 hakkındaki bilişsel yapılarının belirlenmesi amacıyla Dönmez ve Gürbüz (2020) tarafından yapılan çalışmadan elde edilen sonuçların bu çalışmanın sonuçlarına paralel olduğu söylenebilir. Bu noktalar dikkate alındığında ilkokul 3. ve 4. sınıf öğrencilerinin Covid 19 kavramına ilişkin geliştirdikleri bilişsel yapıların en az üniversite öğrencileri kadar geniş bir perspektifte dağglım gösterdiği söylenebilir.

Çalışmadan elde edilen "Covid 19 ile ilgili duyuşsal ifadeler” bilişsel yapısı kapsamındaki ifadelere öğrencilerin özellikle kavrama ilişkin açıklamalarında olmak üzere çizimlerinde de rastlanmıştır. Bu bilişsel yapıdaki en dikkat çeken alt tema öğrencilerin açıklamalarında yer alan "okula özlem" alt temasıdır. $\mathrm{Bu}$ durumun pandemi sürecinden dolayı okulların kapalı olmasından kaynaklandığı açıktır. Bunun dışında öğrencilerin pandemi sürecinden korktuğu, kendini kötü hissettiği, üzüntü duyduğu, virüsten nefret ettiği belirlenmiştir. Duban ve Şen (2020) tarafından yapılan çalışmada ögretmen adaylarının, çocukların okula gidememesinin onları sosyal ve psikolojik olarak sıkıntıya sokacağından endişe duydukları belirlenmiştir. Bu noktaya farklı çalışmalarda değinilerek pandemi sürecinin bireylerde yarattığı özellikle psikolojik etkilerinin yadsınmaz düzeyde olduğu rapor edilmiştir. (Görgülü Arı ve Hayır Kanat, 2020; Kırık ve Özkoçak, 2020).

\section{ÖNERILER}

$\mathrm{Bu}$ araştırmada kısıtlı bir katılımcı ile ilkokul 3. ve 4. sınıf öğrencilerinin Covid 19 kavramı ile ilgili bilişsel yapıları çizme yazma tekniği ile belirlenmeye çalışılmıştır. Katılımcıların niceliksel ve niteliksel özellikleri genişletilerek ve farklı ölçme araçları kullanılarak benzer yönde çalışmalar yapılması önerilebilir. Çalışmada öğrencilerin kavrama ilişkin geliştirdikleri bilişsel yapıların; hastalıktan korunma, hastalığın sebebi, hastalığın sonuçları başta olmak üzere geniş bir perspektifte dağılım gösterdiği belirlenirken hastalığın öğrencilerin psikolojisi üzerine bazı olumsuzluklara sebep olduğu yönünde bulgulara rastlanmıştır. Dolayısıyla tüm dünyada yaşanan bu pandemi sürecinin öğrenciler, öğretmen ve öğretmen adayları gibi farklı kesimler üzerine olan etkileri daha büyük örneklem grupları ile eğitsel, sosyolojik ve psikolojik bağlamda araştırılabilir. 


\section{KAYNAKLAR}

Ak, Ö. (2020). Soğuk algınlığından ölümcül salgına! küresel kâbus, Bilim ve Teknik, 3, 13-27.

Bayburtlu, Y. S. (2020). Covid-19 pandemi dönemi uzaktan eğitim sürecinde öğretmen görüşlerine göre Türkçe eğitimi. Turkish Studies, 15(4), 131-151.

Beyoğlu, A. (2015). Sanat eğitiminde algı, görsel algı ve yanılsama: vıctor vasarely'nin çalışmaları üzerine bir inceleme. Trakya Üniversitesi Sosyal Bilimler Dergisi, 17 (1), 333-348.

Bozkurt, A., Jung, I., Xiao, J., Vladimirschi, V., Schuwer, R., Egorov, G., ... Paskevicius, M. (2020). A global outlook to the interruption of education due to COVID-19 pandemic: navigating in a time of uncertainty and crisis. Asian Journal of Distance Education, 15(1), 1-126.

Bradding, A. \& Horstman, M. (1999). Using the write and draw technique with children. European Journal of Oncology Nursing, 3(3), 170-175. doi: 10.1016/S1462-3889(99)80801-1.

Büyüköztürk, Ş. (2012a). Sosyal bilimler için veri analizi el kitabı. Ankara: Pegem Akademi.

Büyüköztürk, Ş. (2012b). Örnekleme yöntemleri. http://w3.balikesir.edu.tr/ msackes/wp/wpcontent/uploads/17.12.2020.

Büyüköztürk, Ş. Kılıç Çakmak, E., Akgün Özcan, E., Karadeniz Ş. ve Demirel, F. (2018). Eğitimde bilimsel araştırma yöntemleri. (25. Baskı). Ankara: Pegem Akademi.

Byrne, J. (2011). Models of micro-organisms: children's knowledge and understanding of micro-organisms from 7 to 14 years old. International Journal of Science Education, 33 (14), 1927-1961.

Ceylan, Ö. (2015). Fen öğretiminde kavram karikatürü kullanımının 7. sınıf öğrencilerinin akademik başarılarına ve bilişsel yapılarına etkisinin incelenmesi (Yayınlanmamış yüksek lisans tezi). Sakarya Üniversitesi, Eğitim Bilimleri Enstitüsü, İlköğretim Anabilim Dalı Fen Bilgisi Eğitimi Bilim Dalı, Sakarya.

Choi, Y. \& Hong, S. (2014). Perceptions and image analysis of elementary students on scientists studying small organisms. Journal of Korean Elementary Science Education, 33(4), 655-673.

Çepni, S. (2012). Kuramdan uygulamaya: fen ve teknoloji ögrretimi. Ankara: Pegem Akademi Yayıncılık.

Çetin, G., Özarslan, M., Isık, E. ve Eser, H. (2012). Students' views about health concept by drawing and writing technique. Energy Education Science and Technology Part B: Social and Educational Studies, 4(SI1), 311-316.

Dönmez, İ. ve Gürbüz, S. (2020). Üniversite öğrencilerinin Covid-19 virüsü hakkında bilişsel yapılarının belirlenmesi. Manas Sosyal Araşttrmalar Dergisi, 9(4), 2159-2172.

Duban, N. ve Şen, F. G. (2020). Sınıf öğretmeni adaylarının COVID-19 pandemi sürecine ilişkin görüşleri. Turkish Studies, 15(4), 357-376.

Dumais, N., \& Hasni, A. (2009). High school intervention for influenza biology and epidemics/pandemics: impact on conceptual understanding among adolescents. CBE—Life Sciences Education, 8(1), 62-71.

Ekici, G. ve Kurt, H. (2014). Öğretmen adaylarının “AIDS” kavramı konusundaki bilişsel yapıları: bağımsız kelime ilişkilendirme testi örneği. Türkiye Sosyal Araştırmalar Dergisi, 183 (183), 267-306. Retrieved from https://dergipark.org.tr/en/pub/tsadergisi 
Eser, H., Çetin, G., Özarslan, M. ve Işık, E. (2015). Biyoloji öğretmen adaylarının mikroplara ilişkin görüşlerinin çizme-yazma tekniğine göre incelenmesi. Uluslararası Eğitim, Bilim ve Teknoloji Dergisi, 1(1), 17-25.

Görgülü Arı, A. ve Hayır Kanat, M. (2020). Covid-19 (Koronavirüs) üzerine öğretmen adaylarının görüşleri [Özel say1]. Yüzüncü Yll Üniversitesi Sosyal Bilimler Enstitüsü Dergisi, Salgın Hastallklar, 459-492.

Gupta, A., \& Goplani, M. (2020). Impact of covid-19 on educational institutions in india. UGC Care Journal, 661-671. https://doi.org/10.13140/RG.2.2.32141.36321

Gürler, N. H. ve Önder, İ. (2014). 7. sinıf öğrencilerinin fen ve teknoloji dersinde öğrendikleri "bakteri ve virüs" kavramlarını günlük yaşamla ilişkilendirme durumlarının belirlenmesi. III. Sakarya'da Eğitim Araştırmaları Kongresi, 80-86.

Ioannides, C. \& Vosniadou, S. (2001). The changing meaning of force. Cognitive Science Quarterly. 2(1), 562.

Işık, E. ve Çetin, G. (2014). 11. sınıf öğrencilerinin yaşadıkları çevreye ilişkin görüşleri. Journal of Research in Education and Teaching, 3(2), 75- 86.

Kaleli Yılmaz, G. ve Güven, B. (2015). Öğretmen adaylarının uzaktan eğitime yönelik algılarının metaforlar yoluyla belirlenmesi. Turkish Journal of Computer and Mathematics Education (TURCOMAT), 6 (2), 299-322.

Karadon, H.D. ve N. Şahin. 2010. "Primary school students' basic knowledge, opinions and risk perceptions about microorganisms." Procedia Social and Behavioral Sciences, 2, 4398- 4401.

Karahan, E., Bozan, M. A. ve Akçay, A. O. (2020). Sınıf öğretmenliği lisans öğrencilerinin pandemi sürecindeki çevrim içi öğrenme deneyimlerinin incelenmesi, Turkish Studies, 15(4), 201-214. https://dx.doi.org/10.7827/TurkishStudies.44348

Karasar, N. (2012). Bilimsel araştırma yöntemi. Ankara: Nobel Yayınc1lık.

Kılıç, S. (2013). Örnekleme yöntemleri. Journal of Mood Disorders, 3 (1), 44-46. www.jmood.org

Kırı, A. M. ve Özkoçak, V. (2020). Yeni dünya düzeni bağlamında sosyal medya ve yeni koronavirüs (covid-19) pandemisi. The Journal Of Social Sciences, 45 (7), 133-154.

Knippels, M. C. P. J., Waarlo A. J., \& Boersma, K.T. (2005). Design criteria for learning and teaching genetics. Journal of Biological Education, 39(3), 108-112.

Knowles, Z. R., Parnell, D., Stratton, G. \& Ridgers, N. D. (2013). Learning from the experts: exploring playground experience and activities using a write and draw technique. Journal of Physical Activity \& Health, 10(3), 406-415.

Kurt, H. ve Ekici, G. (2013). Virüs nedir? Biyoloji öğretmen adaylarının virüs konusundaki bilişsel yapıları. International Online Journal of Educational Sciences, 5(3), 736-756.

MEB. (2018). T.C. Millî Ĕ̆itim Bakanlı̆̆ı, Fen Bilimleri Dersi Öğretim Programı (İlkokul ve Ortaokul 3, 4, 5, 6, 7 ve 8. Siniflar), Ankara.

Miles, M. B. \& Huberman, A. M. (1994). Qualitative data analysis. C.A: Sage Yayınlar.

Quinn, F., Pegg, J. \& Panızzon, D. (2009). First-year biology students' understandings of meiosis: An investigation using a structural theoretical framework. International Journal of Science Education, 31 (10), 1279-1305 
Sağlık Bakanlı̆̆ı, (2020). Covıd-19 nedir? COVID-19 bilgilendirme sayfasl. https://covid19.saglik.gov.tr/tr66300/covid-19-nedir-.html. 19.12.2020.

Sirem, Ö. ve Baş, Ö. (2020). Okuma güçlüğü olan ilkokul öğrencilerinin Covid-19 sürecinde uzaktan eğitim deneyimleri. Turkish Studies, 15(4), 993-1009. https://dx.doi.org/10.7827/TurkishStudies.43346.

Takmaz, S. ve Yılmaz, M. (2020). Virüs konusunun ortaöğretim öğretim programlarındaki yeri. Anadolu Öğretmen Dergisi, 4(1), 21-43. https://dx.doi.org/10.35346/aod.728962

Taneri, P.O. ve Demir, C.E. (2013). Öğrenci gözüyle hayat bilgisi dersinin işlenişi: Bir nitel araştırma yöntemi olarak yaratıcı drama. İlköğretim Online,12(1), 267-282.

Tongaç, E. (2006). Farklı öğretim yaklaşımlarının öğrencilerin fen bilgisi dersi dolaşım sistemi konusundaki bilişsel yapılarına etkilerinin araştırılması (Yayınlanmamış yüksek lisans tezi). Abant İzzet Baysal Üniversitesi, Bolu.

Topal, Ş. (2006). Biyogüvenlik ve biyoteknoloji. İstanbul: Cemturan Ofset.

Töman, U. ve Çeker, E. (2019). Mikroorganizmaların özelliklerini anlama düzeylerinin belirlenmesine yönelik gelişimsel bir çalışma. Gümüşhane Üniversitesi Sosyal Bilimler Enstitüsü Elektronik Dergisi, 10(3), 570-584.

Tsai, C. C. \& Huang, C. M. (2002). Exploring students' cognitive structures in learning science: A review of relevant methods. Journal of Biological Education, 36, 163-169.

Uçak, N. Ö. ve Güzeldere, Ş. (2006). Bilişsel yapının ve işlemlerin bilgi arama davranışı üzerine etkisi. Türk Kütüphaneciliği, 20 (1), 7-28. Erişim adresi: www.tk.org.tr/index.php

UNDP, Türkiye. (2020). Birleşmiş milletler kalkınma programı 1 covld-19 küresel salgın sürecinde Türkiye'de bakım ekonomisi ve toplumsal cinsiyet temelli eşitsizlikler file:///C:/Users/A\%C4\%B0CU/Downloads

UNESCO, (2020). Education: From disruption to recovery. https://en.unesco.org/covid19/ educationresponse. 23.11.2020

UNICEF, (2020). What is a 'novel' coronavirus? https://www.unicef.org/stories/novelcoronavirus-outbreakshould-know. 23.11.2020

Uzunkaya, A. (2007). Kavram yanılgısı ve çoklu zekâ alanlarının ilişkilendirilmesine dayalı bir öğretimin kavram yanılgılarının giderilmesindeki etkisinin incelenmesi "Mikroorganizmalar" (Yayınlanmamış yüksek lisans tezi). Balıkesir Üniversitesi, Balıkesir.

White, R. T. \& Gunstone, R. F. (1992). Probing understanding. London: The Falmer Press.

WHO, (2020, Nisan). What is a coronavirus? https://www.who.int/news-room/q-a-detail/q-acoronaviruses 23.10.2020

Yalçın, M. ve Erginer, A. (2014). İlköğretim okulu öğrencilerinin okul müdürü kavramına ilişkin yaptıkları çizimler. Eğitim ve Bilim. 39(171), 270-285.

Yıldırım, A. ve Şimşek, H. (2005). Sosyal bilimlerde nitel araştırma yöntemleri (5. Baskı). Ankara: Seçkin Yayıncilik.

Yıldırım, A. ve Şimşek, H. (2011). Sosyal bilimlerde nitel araştırma yöntemleri. Ankara: Seçkin Yayıncılık. 